\title{
The two faces of populism: Between authoritarian and democratic populism
}

\author{
Bojan Bugaric
}

(Received 18 February 2019; accepted 20 February 2019)

\begin{abstract}
Populism is Janus-faced; simultaneously facing different directions. There is not a single form of populism, but rather a variety of different forms, each with profoundly different political consequences. Despite the current hegemony of authoritarian populism, a much different sort of populism is also possible: Democratic and anti-establishment populism, which combines elements of liberal and democratic convictions. Without understanding the political economy of the populist revolt, it is difficult to understand the true roots of populism, and consequently, to devise an appropriate democratic alternative to populism.
\end{abstract}

Keywords: authoritarian populism; democratic populism; Karl Polanyi; political economy of populism

\section{A. Introduction}

There is a tendency in current constitutional thinking to reduce populism to a single set of universal elements. These theories juxtapose populism with constitutionalism and argue that populism is by definition antithetical to constitutionalism. ${ }^{1}$ Populism, according to this view, undermines the very substance of constitutional (liberal) democracy. By attacking the core elements of constitutional democracy, such as independent courts, free media, civil rights and fair electoral rules, populism by necessity degenerates into one or another form of non-democratic and authoritarian order.

In this article, I argue that such an approach is not only historically inaccurate but also normatively flawed. There are historical examples of different forms of populism, like the New Deal in the US, which did not degenerate into authoritarianism and which actually helped the American democracy to survive the Big Depression of the 1930s. Looking at the current populist map, we can also find examples of such democratic populists, which seek to protect and defend democracy by making it more responsive, equitable and inclusive (Sanders, Warren, Podemos, Syriza). Hence, it is wrong to argue that there is something intrinsic to populism, which makes it incompatible with constitutionalism. As Joseph Fishkin and William Forbath argue, many populist movements in the US contributed to the creation of the "anti-oligarchy" concept of constitutionalism, which

\footnotetext{
${ }^{*}$ Bojan Bugaric is an Professor of Law; School of Law, University of Sheffield. This essay is related to, and parts of it are drawn from, a chapter The Populist Backlash Against Europe: Why Only Alternative Economic and Social Policies Can Stop the Rise of Populism in Europe (F. Bignami, ed., EU Law in Populist Times, Cambridge University Press, Forthcoming); and Central Europe's Descent into Autocracy: A Constitutional Analysis of Authoritarian Populism, International Journal of Constitutional Law, 2019, forthcoming. I would like to thank Mark Tushnet for his comments on a draft of this essay. Email: b.bugaric@sheffield.ac.uk

${ }^{1}$ Jan-Werner Müller, What Is Populism? (2016); William Galston, Anti-Pluralism: The Populist Threat to Liberal Democracy (2018); Yascha Mounk, The People vs. Democracy: Why Our Freedom Is in Danger \& How TO SAVE IT (2018).
}

() 2019 The Author. Published by Cambridge University Press on behalf of the German Law Journal. This is an Open Access article, distributed under the terms of the Creative Commons Attribution licence (http://creativecommons.org/licenses/by/4.0/), which permits unrestricted reuse, distribution, and reproduction in any medium, provided the original work is properly cited. 
sought to empower and protect the democratic nature of the American constitution. ${ }^{2}$ We must therefore distinguish between the two different faces of populism: the authoritarian and the emancipatory face of populism. While the former contradicts the key principles of modern democratic constitutionalism, the later seeks to resuscitate the same principles from the grip of the unaccountable "moneyed elites," threating to undermine the very nature of democratic republic.

Populism is Janus-faced; simultaneously facing different directions. There is not a single form of populism, but rather a variety of different forms, each with profoundly different political consequences. Despite the current hegemony of authoritarian populism, a much different sort of populism is also possible: Democratic and anti-establishment populism, which combines elements of liberal and democratic convictions.

Currently we live in an age of populist resentment toward the liberal international order and its core constitutional form-liberal constitutional democracy. ${ }^{3}$ The populist surge is global. Political parties, movements or leaders such as Trump, Kaczynski, Orban, Erdogan, Putin, Salvini, Morales, Maduro, Marine Le Pen, Wilders, to name just a few, claim to be the sole "true" representatives of their peoples against the corrupt elites. ${ }^{4}$ What is peculiar about the current populist surge is the dominance of authoritarian over democratic flavors of populism. The authoritarian populists not only attack the policies that are based on core institutional pillars of this order, but quite often they also challenge the very foundations of liberal order as such.

How is it that nativist, authoritarian populism has become so powerful? The populist backlash in essence represents a delayed Polanyian response to the destructive forces of the unfettered logic of free markets. ${ }^{5}$ As Karl Polanyi demonstrated in his Great Transformation, ${ }^{6}$ when markets become "dis-embedded" from their societies and create severe social dislocations, people eventually revolt. In many countries, populist parties are the only ones to argue that there exists a real alternative. They protest against the "consensus at the center" among the center-right and centerleft around the idea that there is no alternative to neo-liberal globalization.

A nationalist, authoritarian populism, combined with either economic protectionism or almost left-wing-oriented social policy, promises to protect the ordinary people abandoned by the liberal elites. With the eruption of the migration crisis in 2015, such socially-oriented xenophobic nationalism provided an ideal fit connecting the demand and supply side factors and driving increasing numbers of voters away from the political center to more right-wing extremes. As the mainstream center-left discredited itself with its unrelenting pursuit of neo-liberal reforms, the populist parties could claim to fill the void left by other mainstream political parties. In the words of

\footnotetext{
${ }^{2}$ Joseph Fishkin \& William Fortbath, The Anti-Oligarchy Constitution, 94 Boston UnIVersity LaW RevieW 669 (2014). See also David Fontana, Unbundling Populism, 65 UCLA L. Rev. 1482 (2018); and Mark Tushnet, Varieties of Populism, in this issue.

${ }^{3}$ G.John Ikenberry, The End of Liberal International Order, 94 (1) InTERnAtional AfFairs 7 (2018); Edward Luce, ThE Retreat of Western Liberalism 13 (2017); Stefan Rummens, Populism as a Threat to Liberal Democracy, in The Oxford Handbook of Populism 568 (Cristobal Rovira Kaltwasser, Paul Taggart, Paulina Ochoa Espejo, Pierre Ostiguy eds., 2017); Jan Zielonka, Counter-Revolution: Liberal Europe in Retreat 2 (2018). Here, liberal democracy is understood as a political system marked not only by free and fair elections, but also by the rule of law, the separation of powers and the protection of basic freedoms. Andrew Heywood describes liberal democracy as a form of democratic rule "that balances the principle of limited government against the ideal of popular consent.” See ANDrEw HeYwOOd, POLITICS 30 (2002).

${ }^{4}$ John J. Judis, The Populist Explosion: How the Great Recession Transformed American and European Politcs (2016); Müller, supra note 1; CAs Mudde \& Cristobal Rovira Kaltwasser, Populism: A Very SHORT InTroduction (2017).

${ }^{5}$ Robert Kuttner, Can Democracy Survive Global Capitalism? xx-xxii (2018). For a similar argument, in the context of the EU crises, see Matthias Goldmann, The Great Recurence: Karl Polanyi and the crises of the European Union, 23 European Law Journal 272 (2017); Michelle Everson \& Christian Joerges, Reconfiguring the Politics-Law Relationship in the Integration Project through Conflicts-Law Constitutionalism, 18 EUROPEAN LAW JOURNAL 644 (2012).

${ }^{6}$ Karl Polanyi, The Great Transformation: The Political And Economic Origins of Our Time, 2nd ed. (2001).
} 
Cas Mudde, "the populist surge is an illiberal democratic response to decades of undemocratic liberal policies."

Without understanding the political economy of the populist revolt, it is difficult to understand the true roots of populism, and consequently, to devise an appropriate democratic alternative to populism. Yet, surprisingly few studies of current populist explosion venture into this direction. ${ }^{8}$ Most accounts try to explain populism as "the result of impersonal forces," of "globalisation" and "technological change," or even worse, as merely a failure of representative politics, without properly addressing the structural roots of populism, embedded in the political economy of modern capitalism.

What committed democracts of different political camps need to articulate is a coherent alternative to the failed neoliberal economic policies of the last three decades. What counts this time are sensible economic, social, environmental and migraton policies promising to improve daily lives of ordinary citizens. Unfortunately, the politically weakened mainstream parties-the traditional standard bearers of the post-World War II "embedded liberalism" consensus — are now on the defense. Instead of offering novel institutional solutions, the mainstream seems extremely vulnerable to the populist challenge coming both from the extreme right and extreme left. Instead of surrendering to the populists' false promises of quick fixes, the democrats have to reinvent themselves. They must respond to the social anxieties that are helping fuel nationalist populism and offer a vision of new alternative future. Such vision can draw from a rich tradition of democratic populism and its version of anti-establishment constitutionalism.

\section{B. Is populism (always) antithetical to constitutionalism?}

In its broadest sense, populism is an ideology or political movement that "considers society to be ultimately separated into two homogeneous and antagonistic groups, the pure people versus the corrupt elite, and which argues that politics should be an expression of the volonté générale (general will) of the people." 9 Populism seeks to speak in the name of the common people. Its distinctive features are the prioritization of popular sovereignty, direct democracy and a strong emphasis on anti-elitism. Beyond these shared common features, populism emerges in a variety of forms. While populism is hostile to elites, it is also vague and moralistic and as such quite easily instrumentalized by almost any type of ideology, both left and right. Following Paul Taggart's definition of populism, ${ }^{10} \mathrm{I}$ argue that populism is chameleon-like, ever adapting to the colors of its environment. It has no core values and a very thin ideology. Hence, there exist several rather different varieties of populism: agrarian, socio-economic, xenophobic, reactionary, authoritarian and progressive populism. ${ }^{11}$ In order to fully understand the logic of the different populisms, we have to approach them as socially and historically contingent categories. Besides the global factors mentioned earlier, we also have to study local conditions and factors, which help explain a variety

\footnotetext{
${ }^{7}$ Cas Mudde, Europe's Populist Surge, 95 Foreign AfFairs 25 (2016).

${ }^{8}$ Adam Tooze, Balancing Act, DissEnT (2018); distinguishing two current works, which deal with the political economy of populism: Kuttner, supra note 5; and Barry Eichengreen, The Populist Temptation: Economic Grievance And Political Reaction In The Modern Era (2018). See also Kim Lane Scheppele, The Opportunism of Populists and the Defense of Constitutional Liberalism, in this issue (arguing that populists are in essence authoritarians strategically using the label of populism in their quest for raw power).

${ }^{9}$ Cas Mudde, The populist zeitgeist, 39 Government And Opposition 543 (2004).

${ }^{10}$ Paul A. Taggart, Populism 4 (2000).

${ }^{11}$ Margaret Canovan, Populism (1981); Noam Gidron \& Bart Bonikowski, Varieties of Populism: Literature Review and Research Agenda, Weatherhead Center for International Affairs, Harvard University, Working Paper Series no.13-0004 (2013), available at: https://scholar.harvard.edu/files/gidron_bonikowski_populismlitreview_2013.pdf; Cas Mudde \& Cristobal Rovira Kaltwasser, Populism, in The Oxford Handbook of Political Ideologies 495-498 (Michael Freeden \& Marc Stears eds., 2013).
} 
of forms that populist movements assume. As Anna Grzymala Busse argues, rather than analyzing populism per se, we should recognize that it takes a variety of guises. ${ }^{12}$

Curiously enough, despite the variety of forms that populism can assume, there is a tendency in current constitutional thinking to reduce populism to a single set of universal elements. These theories juxtapose populism with constitutionalism and argue that populism is by definition antithetical to constitutionalism. ${ }^{13}$ Populism, according to this view, undermines the very substance of constitutional (liberal) democracy.

According to Jan-Werner Müller, populism has an "inner logic" that consists of two essential elements. The first key ingredient of populism is moralized anti-pluralism. According to Muller, populists are not only anti-elitist, but always also anti-pluralist. Leaders like Orbán, Kaczynski and Trump claim that "they, and they alone, represent the people." ${ }^{14}$ In their worldview, there are no opponents, only traitors. The opposition leaders are delegitimized through being cast as not caring about ordinary Polish and Hungarian citizens, but only about the interests of various "liberal" elites. Hence, on Müller's reading, populism's essential trait is a rejection of pluralism.

The second element, the noninstitutionalized notion of the people, means "that the populist asserts or assumes that there is a singular and morally privileged understanding or will that has not been manifest through the formal structures of democratic choice." 15 The role of the populist leader is to do what the people want. The formal structures of liberal democracy have to be put aside if they are preventing the populist leader to fulfill his role. Populist leaders distrust all the traditional institutions of liberal democracy that stand between them and the wishes of the people. As a result, many of the populist parties openly flout the rule of law and explicitly reject the values of liberal democracy. A corollary of this element is the strong personalization of power, reflected in the fact that strong leaders like Orbán and Kaczyinski have managed to concentrate almost unlimited political power in their hands.

Portrayed in this way, populism becomes almost identical to authoritarianism and dictatorship. The hallmarks of populist style in power are colonization of the state, mass clientelism and mass corruption, and the systematic repression of civil society. ${ }^{16}$ It is no surprise then that Müller views populism essentially as "a permanent shadow of modern representative democracy, and a constant peril."17 In light of the particular type of populism that has evolved in East Central Europe, most notably in Hungary and Poland, most of Müller's claims seem accurate. The new authoritarian populism in ECE differs from other populisms because it combines the elements of populism, ethno-nationalism and authoritarianism. The authoritarian populists in Hungary and Poland have successfully institutionalized, through legal reforms, a new version of semi-authoritarian regime, which is halfway between "diminished democracy" and "competitive authoritarianism." 18 Following a similar script, which consists of sustained attacks on rule of law institutions, civil rights and freedoms, the media and electoral rules, both leaders in a relatively short period of time dismantled almost all the key cornerstones of democracy in Hungary and Poland. ${ }^{19}$ While Müller's definition accurately captures the "inner logic" of one particular type of populism,

\footnotetext{
${ }^{12}$ Anna Grzymala Busse, Global Populisms and Their Impact, 76 SLAVIC Review 3 (2017).

${ }^{13}$ For an excellent overview of these theories see Gabor Halmai, Is There Such A Thing As 'Populist Constitutionalism? The Case of Hungary, 11 FudAn Journal of THE HumAnities AND Social SCIENCES 323 (2018); see also Gabor Halmai, Populism, Authoritarianism, and Constitutionalism, in this issue; contra, see Paul Blokker, Varieties of Populist Constitutionalism: The Transnational Dimension, in this issue.

${ }^{14}$ Müller, supra note 1 , at 20.

${ }^{15}$ Aziz Z. Huq, The People Against the Constitution, 116 Mich. L. Rev. 1123 (2018).

${ }^{16}$ Müller, supra note 1 , at $44-48$.

${ }^{17} I d$. at 11.

${ }^{18}$ On diminshed democracy, see David Collier \& Steven Levitsky, Democracy with Adjectives: Conceptual Innovation in Comparative Research, 49 WORLD Politics 430-451 (1997), on competitive authoritarianism, see Steven Levitsky \& Lucian A.Way, Competitive Authoritarianism: Hybrid Regimes After The Cold War (2010).

${ }^{19}$ Grzegorz Ekiert, How to Deal with Poland and Hungary, 13 Social Europe Occasional Paper 2 (2017).
} 
authoritarian populism, it leaves out many other possible types of populism, which do not necessarily share the same characteristics.

In his critique of Müller, Bart Bonikowski argues that populist claims need not lead to authoritarian governance and that authoritarianism can rely on a variety of other legitimating discourses besides populism. ${ }^{20}$ Furthermore, Bonikowski points out that "populism has also been employed by mainstream politicians who operate within the constraints of democratic institutions. And even when populist movements have radical origins, the resulting political outcomes can be benign with respect to democratic stability." 21 In this vein, Bonikowski mentions the People's Party in the United States and the Brexit campaign in the United Kingdom. Marco D'Eramo and Daniel Steimetz-Jenkins criticize Muller's definition of populism for excluding a a figure like Bernie Sanders from the ranks of the populists. ${ }^{22}$ Mark Tushnet offers the most poignant critique of such a "generic" approach to populism:

Most academic writing has focused on the right-wing versions. That writing generates critiques of what the authors describe as generic populism, critiques that the authors then apply to left-wing populism. It seems to me, though, that the critiques are mostly concerned with the "right-wing-ness" of the object of study, but present themselves in politically neutral terms-presumably because direct political criticism would seem unscholarly. ${ }^{23}$

In a similar fashion, Thomas Frank criticizes Yascha Mounk and William Galston, who in their account of populism almost completely ignore other historical versions of populism. Frank lists several historical figures associated with progressive and democratic populism in the United States: Andrew Jackson, the Populist Party, and FDR. Frank also reminds us of an alternative definiton of populism, offered by historian Lawrence Goodwyn; in the opening statement of his book, The Populist Moment, Goodwyn argues that "This book is about the flowering of the largest democratic mass movement in American history. It is also necessarily a book about democracy itself." 24 For Goodwyn, populism represented "a vision of democratic participation that was actually more advanced than what we settle for today. Far from being a threat to democracy, Populism was democracy's zenith."25

Building on this tradition of democratic populism, Dani Rodrik argues that economic populism, which puts the people's interest before the interests of autonomous regulatory agencies, independent central banks, and global trade rules, can sometimes be justified:

In such cases, relaxing the constraints on economic policy and returning policymaking autonomy to elected governments may well be desirable. Exceptional times require the freedom to experiment in economic policy. Franklin D. Roosevelt's New Deal provides an apt historical example. FDR's reforms required that he remove the economic shackles imposed by conservative judges and financial interests at home and by the gold standard abroad. ${ }^{26}$

In line with Rodrik's position, Robert Howse distinguishes the policies of good (economic) populism from bad (political) populism. The policies of good populism, according to Howse, "will be

\footnotetext{
${ }^{20}$ Bart Bonikowski, Ethno-nationalist populism and the mobilization of collective resentment, 68 THE BRITISH JOURNAL OF SOCIOLOGY 189-190 (2017).

${ }^{21} I d$. at 190.

${ }^{22}$ Daniel Steinmetz-Jenkins, The Logic of Populism, 64 Dissent (2017); Marco D’Eramo, They, The People, 103 NEw LEFT REVIEW 129 (2017).

${ }^{23}$ Mark Tushnet, Comparing Right-Wing and Left-Wing Populism, in CONSTITUTIONAL Democracy In Crisis? 639 (Mark A.Graber, Sanford Levinson, Mark Tushnet eds., 2018).

${ }^{24}$ Lawrence Goodwyn, The Populist Moment: A Short History Of The Agrarian Revolt In America (1978).

${ }^{25}$ Thomas Frank, Forget Trump - populism is the cure, not disease, The GUARDIAN, May 23, 2018.

${ }^{26}$ Dani Rodrik, In Defence of Economic Populism, Project Syndicate, Jan. 18, 2018.
} 
consistent with inclusion and pluralism-on the economic side, as Rodrik suggests, these would be New Deal-like initiatives that tax and regulate the wealthy, large businesses, but all the while allowing them to participate and continue to thrive in the polity. ${ }^{27}$ Moreover, Howse identifies Bernie Sanders' proposal to redistribute wealth without being confiscatory, to constrain the excesses of contemporary financial capitalism, not to nationalize the financial system, and to replace private with public capitalism, as belonging to this version of good/economic populism.

Looking at the current populist map, we can also find examples of democratic populists who seek to protect and defend democracy by making it more responsive, equitable and inclusive. Pippa Norris and Ronald Englehart argue that "populist parties, leaders and social movements with more liberal values are less common as a type but their support has also grown in recent years in several European states. These typically blend populist discourse railing against corruption, mainstream parties and politicians, capitalism combined with the endorsement of socially-liberal attitudes, left-wing economic policies and participatory styles of engagement." 28 This category includes Spain's Podemos party, Greece's Syriza, the Left party in Germany, the Socialist Party in Netherlands, Bernie Sanders, Elizabeth Warren and Alexandria Ocasio-Cortez in the United States. These examples of democratic, liberal, socially inclusive forms of populism quite clearly show that authoritarianism and anti-pluralism are not necessarily the key elements of populism. Despite the current hegemony of authoritarian populism, a far different sort of populism is possible: democratic and anti-establishment populism, which combines elements of liberal and democratic convictions.

\section{The dominance of right-wing authoritarian populism}

What is peculiar about the current populist surge is the dominance of authoritarian over democratic populism. ${ }^{29}$ How is it that nativist, authoritarian populism has become so powerful? Without understanding the political economy of the populist revolt, it is difficult to understand the true roots of populism, and consequently, to devise an appropriate democratic alternative to populism. Yet, surprisingly few studies of current populist explosion venture into this direction. Most of the accounts try to explain populism as "the result of impersonal forces," of "globalisation" and "technological change," or even worse, as merely a failure of representative politics, without properly addressing the structural roots of populism, embedded in the political economy of modern capitalism. Samuel Moyn and David Priestland criticize approaches which focus only on the perceived threat of populism to liberal fundamentals and argue for a stronger emphasis on "the deeply rooted forces that have been fueling right-wing populist politics, notably economic inequalities and status resentments." ${ }^{30}$ In what follows, I offer a brief political economy analysis of the populist backlash in Europe.

The European Union is facing an unprecedented political crisis. This club of liberal and democratic countries has been confronted by a nationalist and populist backlash that threatens the core principles at the very heart of the EU. ${ }^{31}$ Capitalizing on the European sovereign debt crisis, the backlash against refugees streaming in from the Middle East, public angst over the growing terror threat, and Brexit, previously fringe populist political parties are growing with alarming speed. Populists not

\footnotetext{
${ }^{27}$ Robert Howse, Populism and Its Enemies, 17 InT. J. OF CONST'L L. (2019), forthcoming.

${ }^{28}$ Pippa Norris \& Ronald Inglehart, Cultural Backlash: Trump, Brexit And Thr Rise Of Authoritarian POPULISM 12 (2019).

${ }^{29}$ Revealed: One in Four Europeans Vote Populist, The Guardian, Nov. 20, 2018; Institute for Global Change, European Populism: Trends, Threats, and Future Prospects (2017); Jeremy Ashkenas \& Gregor Aisch, European Populism in the Age of Donald Trump, The New York Times, Dec. 5, 2016, https://www.nytimes.com/interactive/2016/ 12/05/world/europe/populism-in-age-oftrump.html.

${ }^{30}$ Samuel Moyn \& David Priestland, Trump Isn't A Threat to Our Democracy. Hysteria is, The New York TIMES, Aug. 11, 2017.

${ }^{31}$ The European Union In Crisis (Desmond Dinan, Neil Nugent \& William Paterson eds., 2017); James KirChick, The End of Europe: Dictators, Demagogues, And the Coming Dark Age (2017).
} 
only attack policies that are based on core institutional pillars of the European integration project, but quite often they also challenge the very foundations of the project as such.

Part of the blame for the populist upsurge falls on both center-right and center-left party leaders who have failed to respond effectively to the European debt crisis. This fact is often obscured by the current focus on the migrant crisis as the single most important contributor to the populist surge. As Vivien Schmidt correctly argues, it is "neo-liberalism gone too far" 32 that is the major contributor to the anger fueling the rise of populism in Europe. There are also other rival theories attempting to explain the current rise of populism, which point to a variety of structural factors, ranging from the effects of globalization and global trade on income distribution, ${ }^{33}$ to a decline in the subjective social status of white men, ${ }^{34}$ and, last but not least, to culture-where populism is a reaction against progressive cultural change. ${ }^{35}$

Although the roots of populism are complex, austerity and neoliberal structural reforms are undoubtedly one of the most important underlying factors. The ruling parties' obsession with fiscal austerity and with supply-side policies of privatization, deregulation, and liberalization, effectively triggered a "lost decade" of economic stagnation, rising unemployment, increasing poverty, and dwindling EU solidarity that paved the way for the poisonous ultra-nationalism now on the rise. ${ }^{36}$ All this has driven trust in the EU to an all-time low and fueled pathologies not seen since the 1930s, placing the European integration project on truly precarious ground. The new populist "zeitgeist" is best described by Jan Zielonka, who argues that "under attack is not just the EU but also other symbols of the current order: liberal democracy and neo-liberal economics, migration and a multicultural society, historical 'truths' and political correctness, moderate political parties and mainstream media, cultural tolerance and religious neutrality." 37 Moreover, while populism comes in many versions, what almost all populists in Europe share is the rejection of "people and institutions that have governed Europe in the last three decades." 38

In many countries, populist parties are the only ones to argue that there exists a real alternative. They protest against the "consensus at the center"-between the center-right and center-leftaround the idea that there is no alternative to neo-liberal globalization. In the eyes of populists, the European project is the embodiment of a ruthless process of globalization responsible for intolerable levels of inequality, declining trust in democracy, a rising danger of terrorism, and increasing fear of loss of one's "national" and "cultural" identity. Many major populist parties in Western Europe today are both anti-Eurozone and anti-European. On the left, only populists in Greece and Spain support both the euro and the European project. On the right, only two major populist parties (Germany's right-wing AfD and Italy's Five Star Movement) are not outright antiEuropean, but they are both against the euro. ${ }^{39}$ The populists in the East have gone even farther in their confrontation with the EU. They frontally assault core EU values, contest the legitimacy of EU institutions and policies, and, at home, dismantle constitutional democracy.

A stronger showing of the right-wing populists in Europe is largely attributable to the decline of social democratic or center left. Support for parties that once commanded over 40 per cent of votes

\footnotetext{
${ }^{32}$ Vivien Schmidt, Missing Topic In \#EUref: Neo-Liberalism Gone Too Far, Social Europe, June 22, 2016, https://www. socialeurope.eu/missing-topic-euref-neo-liberalism-gone-far; see also Jürgen Habermas, "New" Perspectives for Europe, Social EuRope, Oct. 22, 2018, https://www.socialeurope.eu/new-perspectives-for-europe.

${ }^{33}$ Dani Rodrik, Populism and the Economics of Globalization, Journal Of International Business Policy 1 (2018).

${ }^{34}$ Noam Gidron and Peter A. Hall, The Politics of Social Status: Economic and Cultural Roots of the Populist Right, 68 British Journal OF Sociology 57 (2017).

${ }^{35}$ Ronald F. Inglehart \& Pippa Norris, supra note 28.

${ }^{36}$ Barry Eichengreen, supra note 8, at 163.; Jason Beckfield, European Integration and Income Inequality, 71 AMERICAN Sociological Review 964 (2006); Jason Beckfield, Unequal Europe: How Regional Integration Reshaped the Welfare State and Reversed the Egalitarian Turn (2019).

${ }^{37}$ Jan Zielonka, Counter-Revolution: Liberal Europe In Retreat 2 (2018).

${ }^{38} I d$., at 3 .

${ }^{39}$ Jeremy Ashkenas \& Gregor Aisch, supra note 29.
} 
has dropped precipitously. The French Socialist Party, for instance, dropped to 6 per cent in the last parliamentary elections. The Greek PASOK fell from 44 per cent to only 6 per cent, and the Dutch Labor Party (PvDA) from 27 to 6 per cent. ${ }^{40}$ As Sheri Berman argues,

Many traditional social democratic voters now vote populist; social democracy's embrace of a "kinder, gentler" neoliberalism opened a policy "space" populists filled with welfare-state chauvinism; and social democracy's fading electoral fortunes have rendered majority left government and, in many European countries, any stable majority government impossible, making it more difficult to solve problems, increasing dissatisfaction with democracy and support for populism further. ${ }^{41}$

The populist backlash in essence represents a delayed Polanyian response to the destructive forces of the unfettered logic of free markets. ${ }^{42}$ As Karl Polanyi demonstrated in his Great Transformation, ${ }^{43}$ when markets become "dis-embedded" from their societies and create severe social dislocations, people eventually revolt. Despite important differences between the new populist forces in Europe, they have "more in common than we think. They are all pro-welfare (for some people, at least), anti-globalization, and most interestingly, pro-state, and although they say it sotto voce on the right, anti-finance." ${ }^{4}$ As Chantal Mouffe argues, populists are not against the European project as such, but only against "the neo-liberal incarnation of the European project." 45

Vindication of "the social" by the populist forces does not mean only a defense of social rights but also a demand for greater autonomy of Member States on cultural (identity) and economic issues. ${ }^{46}$ The populists do not seek to completely dismantle the EU. They do, however, demand that their national sovereignty be "restored" and oppose any further attempts toward an "ever closer union." Much like in the 1930s, the protagonists of "the social" appear in different political forms, ranging from the extreme right to the extreme left on the political spectrum. While populist forces often pose legitimate political questions about the current state of democracy in Europe, their solutions tend to be controversial. ${ }^{47}$ Their visions of emancipating "the social" often bear an uncanny resemblance to illiberal and authoritarian ideals from the 1930s.

\section{E. Why only alternative economic and social policies can stop the rise of populism in Europe}

In order to defuse the steady rise of populism in Europe, European democrats should articulate a coherent alternative to the failed neoliberal economic policies of the last decade. What counts this time are sensible economic, social and environmental policies promising to improve daily lives of European citizens. The EU needs to regain credibility by delivering simple and palpable benefits, such as good salaries, decent pensions, high-quality social services, and high environmental standards. In other words, it needs to improve what political theorists define as "output

\footnotetext{
${ }^{40}$ Giacomo Benedetto \& Simon Hix, The Rise and Fall of Social Democracy, 1918-2017, unpublished paper.

${ }^{41}$ Sheri Berman, Politics, Pessimism, and Populism, SocIal Europe, Oct. 10, 2018; Sheri Berman, The Lost Left, 27 JournaL OF Democracy 69 (2016).

${ }^{42}$ Kuttner, supra note 5.

${ }^{43}$ Polanyi, supra note 6.

${ }^{44}$ Mark Blyth, Global Trumpism: Why Trump's Victory was 30 Years in the Making and Why It Won't Stop Here, FOREIGN AfFAIRs, Nov. 15, 2016, https://www.foreignaffairs.com/articles/2016-11-15/global-trumpism.

${ }^{45}$ Chantal Mouffe, In Defence of Left-Wing Populism, The Conversation, April 29, 2016, http://theconversation.com/indefence-of-left-wing-populism-55869; see also Chantal Mouffe, For A Left Populism (2018).

${ }^{46}$ For a legal analysis of these issues, see Gráinne de Búrca, Is EU Supranational Governance a Challenge to Liberal Constitutionalism?, 85 U. CHI. L. REV. 337 (2018).

${ }^{47}$ Cristóbal Rowira Kaltwasser, The Response of Populism to Dahl's Democratic Dilemmas, 62 POLITICAL STUDIES 470 (2014).
} 
legitimacy." 48 Only an economic policy that promotes growth, better jobs, wages, and social inclusion can stem the nationalist tide. To prevent history from repeating itself, Europe must act now.

Since the beginning of the Eurozone crisis in 2009, governments across Europe have singlemindedly embraced fiscal austerity. This has meant double-digit government spending cuts, and the elevation of the austerity paradigm spearheaded by German Chancellor Angela Merkel to an essentially "unbreakable law." The new Fiscal Compact, a treaty signed by all EU members except the United Kingdom and the Czech Republic, effectively outlaws the counter-cyclical economic policies espoused by Keynesianism, and establishes austerity and balanced budgets as the new fundamental principles of the EU constitutional order. ${ }^{49}$ The problem is that this myopic austerity focus rests on a misdiagnosis of the euro crisis, has backfired economically, and has triggered grave social and economic repercussions in indebted countries. ${ }^{50}$ Nevertheless, austerity remains the virtually unchallenged "official" EU economic doctrine. What Europe needs more than anything is a new anti-austerity coalition, focused on growth and social justice. Only a Europe willing to revert back to some basic Keynesian policies of economic stimulus, as the US government did at the outset of Barack Obama's presidency, combined with economic innovations that include much-needed investments in infrastructure, education, and social programs, can restore Europe to stability, and reverse its dangerous nationalist surge.

Barry Eichengreen offers an economic explanation on why only a re-nationalization of fiscal policy can stem the tide of European populism. ${ }^{51}$ His core thesis is that the evidence for large cross-border spillovers of national fiscal policies is weak. At the same time, the core questions of fiscal policy-whom to tax, how to tax, and how much to tax-are one of the most sensitive political and social questions, which are quintessentially national prerogatives. When crosscountry spillovers are small but national preferences differ, the best option is to leave the decision-making at the national level. He concludes: "For fiscal policy then, the appropriate reform is less Europe, not more Europe." 52 Similarly, Vivien Schmidt notes that "the EU needs to give back to the member-states the flexibility they have had in the past to devise policies that work for them." 53 To this end, a more bottom-up and flexible reinterpretation of the rules of Eurozone governance is required: "[T]he Eurozone already has an amazing architecture of economic coordination, reaching into all the Eurozone ministries of finance and country economic experts. Why not use that coordination to ensure that countries themselves determine what works for their very specific economic growth models and varieties of capitalism?" 54 The existing framework of

\footnotetext{
${ }^{48}$ See Vivien Schmidt, Democracy and Legitimacy in the European Union Revisited: Input, Output and Throughput, 61 Poltical Studies 2 (2013).

${ }^{49}$ Treaty on Stability, Coordination and Governance in the Economic and Monetary Union [hereinafter TSCG]. It was signed on March 2, 2012 and it entered into force on January 1, 2013, available at https://www.consilium.europa.eu/ media/20399/st00tscg26_en12.pdf (not published in the OJEU). See Fintan O'Toole, Treaty Seeks to Outlaw One Side of the Debate, The Irish Times, March, 6, 2012, https://www.irishtimes.com/opinion/treaty-seeks-to-outlaw-one-side-of-thedebate-1.476193.

${ }^{50}$ In an important study, three economists from the IMF argue that austerity policies can do more harm than good. Jonathan D. Ostry, Prakash Loungani \& Davide Furceri, Neoliberalism Oversold?, 53 FINANCE AND DEVELOPMENT 38 (2016); see also Paul de Grauwe \& Yuemei Ji, The Legacy of Austerity in the Eurozone, CEPS Commentary, October 4, 2013.

${ }^{51}$ Eichengreen, supra note 8, at 168-70. See also Barry Eichengreen, The Euro's Narrow Path, ProjeCt SyndiCATE, September 11, 2017; Barry Eichengreen \& Charles Wyplosz, Minimal Conditions for the Survival of the Euro, Vox, March 14, 2016, https://voxeu.org/article/minimal-conditions-survival-euro.

${ }^{52}$ Eichengreen, supra note 9, at 169. An important precondition for such re-nationalization of fiscal policy is that banks be prevented from holding dangerous numbers of government bonds. However, for a critique of this argument, see Dani Rodrik, Does Europe Really Need Fiscal and Political Union, Project SYNDICATE, Dec. 11, 2017, https:/www.project-syndicate.org/ commentary/separating-private-and-public-finance-in-europe-by-dani-rodrik-2017-12. See also Peter Lindseth, The Democratic Disconnect, the Power-Legitimacy Nexus, and the Future of EU Governance, in EU LAW IN POPULIST TIMES (Francesca Bignami ed., 2019), forthcoming, endorsing renationalization of fiscal policy.

${ }^{53}$ Vivien Schmidt, How Should Progressives Respond to the EU's Many Crises and Challenges to Democracy?, THE Progressive Post, April 3, 2017, https://progressivepost.eu/progressives-respond-eus-many-crises-challenges-democracy/. ${ }^{54} I d$.
} 
the European Semester, ${ }^{55}$ redesigned in this way, could help Member States to get back on the path of sustainable growth. The fiscal councils could be supplemented by new competitiveness councils to act more as industrial policy councils rather than structural adjustment hawks; in Schmidt's words, "such a bottom-up approach is likely not only to promote better economic performance but also much more democratic legitimacy at the national level. This is because it would put responsibility for the country's economics back in national government's hands at the same time that it would encourage more legitimising deliberation at the EU level." ${ }^{56}$ But in order to be redesigned in the suggested way, the European Semester would require simultaneous changes of SGP rules as well. As Mark Dawson argues, the European Semester "was envisaged as a measure to buttress and strengthen the Eurozone economy in particular and to recognise the need for heightened EU supervision of domestic budgets." 57 As a result, it is deeply embedded in the balanced budget fundamentalism of the SGP. ${ }^{58}$

However, none of these suggested reforms will work if the troubled countries remain overburdened by excessive debt and if they are left bereft of significant investment funds provided by banks or the state. For all this, the European Stability Mechanism is simply not enough. The EU needs to reinvent new forms of solidarity. As Schmidt suggests, new instruments such as Eurobonds, Europe-wide unemployment insurance, EU investment resources ${ }^{59}$ and an EU self-generated budget are needed. The first step in this direction was made in 2015 through the establishment of the European Fund for Strategic Investments (EFSI), part of the Investment Plan for Europe (the so-called Juncker Plan). ${ }^{60}$ EFSI is an initiative launched jointly by the European Investment Bank and the European Commission to help overcome the current investment gap in the EU. However, as a recent study of the political economist Cornel Ban shows, ${ }^{61}$ most EFSI loans and guarantees so far have gone to countries in a relatively strong economic position, with the exception of Italy and Spain, which at the time were undergoing steep recessions. In other words, Italy, Spain, France, Germany, and Poland received most of the loans, whereas the Baltic countries, Hungary and Romania received dramatically less. As a result, "the countercyclical pattern looks quite patchy." 62

One possible lesson to draw from this quite limited example of European "Keynesianism" is that the creation of a new anti-austerity coalition will not be an easy task. As Jeffrey Frieden and Stefanie Walter show, the outcome of the crisis has been quite unusual "because the costs of the crisis resolution have been borne almost exclusively by the debtor countries and taxpayers in the

\footnotetext{
${ }^{55}$ The European Semester is a cycle of economic and fiscal policy coordination within the EU. It is part of the European Union's economic governance framework. Its focus is on the six-month period from the beginning of each year, hence its name-the "semester." During the European Semester, the Member States align their budgetary and economic policies with the objectives and rules agreed at the EU level. The legal basis for European Semester is the so-called Six Pack, European Parliament and Council Regulation No. 1175/2011. For a detailed analysis of the European Semester, see Philomila Tsoukala, Post-Crisis Economic and Social Policy: Some Thoughts on Structural Reforms 2.0., 2100 GEORGETOWN LAW Faculty Publications AND OTHer Works (2019) https://scholarship.law.georgetown.edu/facpub/2100.

${ }^{56}$ Vivien Schmidt, How Do Progressives Fight Back Against Populism, SocIAL Europe, April 4, 2017, https://www. socialeurope.eu/author/vivien-schmidt.

${ }^{57}$ Mark Dawson, New Governance and the Displacement of Social Europe: The case of the European Semester, 14 European Constitutional Law Review 196 (2018).

${ }^{58}$ For this point, see Dawson, supra note 57; Francesco Costamagna, National Social Spaces as Adjustment Variables in the EMU: A Critical Legal Appraisal, 24 European Law Journal 163 (2018).

${ }^{59}$ For a critical assessment of the Juncker Plan (European Fund for Strategic Investments), see CORNEL BAN, AUSTERITY Europe, Keynesian Europe: The Politics of Debt and Growth in Europe, unpublished manuscript (2017).

${ }^{60}$ European Parliament and Council Regulation 2015/1017, On the European Fund for Strategic Investments, the European Investment Advisory Hub and the European Investment Project Portal and amending Regulations (EU) No 1291/2013 and (EU) No 1316/2013 - the European Fund for Strategic Investments, 169 O.J. (2015) 1.

${ }^{61}$ Ban, supra note 59.

${ }^{62} I d$.
} 
Eurozone." 63 The rift between the debtor and creditor states that emerged as the consequence of this outcome implicates "powerful national interests and equally powerful particularistic special interests." ${ }^{64}$ It is one thing to say that the survival of the Eurozone is in the interest of both groups of countries but quite another to persuade German, Dutch, Austrian and other mostly Northern European surplus countries to agree to a more debtor-friendly version of adjustment policies.

What the EU needs is not only more financial resources, but also new ideas about how to create more inclusive, diverse, and pluralistic European societies and economies. Here I agree with Aglietta, who argues:

Integration in the absence of a Europe-wide development strategy succeeded only in concentrating industrial activity in the regions where it was already strong, while the periphery lost ground. To counter this slide into long-term stagnation will require a development project capable of relaunching innovation across the whole range of economic activities, driven by investment largely anchored at regional and local level, with a strong environmental component. ${ }^{65}$

If countless billions were found to prop up large European financial institutions, it is not implausible to think a small fraction of that sum could be devoted to such a development project. The future of the EU will be determined by the ability of European political forces and civil society to articulate and push forward alternative scenarios for such "possible Europes."

\section{F. Conclusion}

Unfortunately, the politically weakened European mainstream parties-the traditional standard bearers of the post-World War II "embedded liberalism" consensus - are now on the defense. Instead of offering novel progressive solutions, the mainstream seems extremely vulnerable to the populist challenge coming both from the extreme right and extreme left. Instead of surrendering to the populists' false promises of quick fixes, the mainstream has to reinvent itself. It must respond to the social anxieties that are helping fuel nationalist populism. Populist leaders are promising better pensions, health care and more jobs, an agenda that is winning over the abandoned working class communities that were once a stronghold of the European social democratic and other progressive parties. Leaders of socially oriented, pro-liberal parties can reverse the nationalist trend by returning the EU to its initial role as the promoter of European solidarity and equality. Job training and 'green' growth are just some of the possible public investments in this direction. As Greece's humiliating defeat by the German-led austerity coalition illustrates, this will take a concerted, Europe-wide initiative. ${ }^{67}$ If European democrats of various political colours do not start offering a more compelling agenda, Europe is on a dangerous political path.

\footnotetext{
${ }^{63}$ Jeffry Frieden \& Stefanie Walter, Understanding the Political Economy of the Eurozone Crisis, 20 ANNUAL REVIEW OF POLITICAL SCIENCE 371 (2017).

${ }^{64} I d$., at 386.

${ }^{65}$ Michel Aglietta, The European Vortex, 75 New Left Review 15 (2012).

${ }^{66}$ Alain Supiot, Possible Europes, 55 New Left Review 57 (2009).

${ }^{67}$ In summer 2015, the EU imposed harsh loan terms on Greece even though they were previously rejected by popular referendum.
}

Cite this article: Bugaric B (2019). The two faces of populism: Between authoritarian and democratic populism. German Law Journal 20, 390-400. https://doi.org/10.1017/glj.2019.20 